\title{
Cloning and characterization of a type 1 metallothionein gene from the copper-tolerant plant Elsholtzia haichowensis
}

\author{
Yan Xia $\cdot$ Yanyan Lv $\cdot$ Yuxiang Yuan $\cdot$ Guiping Wang $\cdot$ \\ Yahua Chen $\cdot$ Hongsheng Zhang $\cdot$ Zhenguo Shen
}

Received: 29 November 2011 / Revised: 3 March 2012/ Accepted: 6 March 2012/Published online: 21 March 2012

(C) The Author(s) 2012. This article is published with open access at Springerlink.com

\begin{abstract}
EhMT1, a type 1 metallothionein (MT) gene, was cloned from Elsholtzia haichowensis, a Cu-tolerant plant. Typical of plant type $1 \mathrm{MTs}$, EhMTl encodes a putative peptide of 74 amino acid residues containing cysteine-rich domains. Sequence comparisons with various databases revealed strong similarities at the nucleotide and amino acid levels between EhMT1 and the type 1 MT of Mimulus guttatus. EhMT1 transcription was greater in the roots than in the leaves, and was markedly increased by treatments with $\mathrm{Cu}, \mathrm{H}_{2} \mathrm{O}_{2}$, and heat shock. EhMT1-GUS was localized to the cytoplasm of onion epidermal cells. Escherichia coli cells expressing pET-30aEhMT1 were more tolerant to $\mathrm{Cu}$ and accumulated more $\mathrm{Cu}$ than control cells. Our results show that EhMTl is involved in $\mathrm{Cu}$ tolerance and accumulation in E. haichowensis.
\end{abstract}

Keywords Copper tolerance and accumulation . EhMT1 · Elsholtzia haichowensis · Gene expression · Metallothionein

\section{Introduction}

Soil contamination with heavy metals has become a serious environmental problem due to human practices such as

Communicated by T. Moriguchi.

Y. Xia · Y. Lv · Y. Yuan · G. Wang · Y. Chen · Z. Shen $(\bowtie)$ College of Life Sciences, Nanjing Agricultural University, 210095 Nanjing, The People's Republic of China e-mail: zgshen@njau.edu.cn

H. Zhang

State Key Laboratory of Crop Genetics and Germplasm Enhancement, Nanjing Agricultural University, 210095 Nanjing, The People's Republic of China mining, metallurgy, disposal of sewage sludge, and the agricultural application of fertilizers, pesticides, and wastes. Copper $(\mathrm{Cu})$ is an essential micronutrient with catalytic and structural roles in plant growth and development. However, excess $\mathrm{Cu}$ can be toxic to plants, causing a wide range of deleterious effects, such as the inhibition of photosynthesis and pigment synthesis, plasma membrane damage, functional changes, and other metabolic disturbances (Marschner 1995). The normal leaf $\mathrm{Cu}$ concentration in plants ranges from 5 to $30 \mu \mathrm{g} / \mathrm{g}$ dry weight (DW) (Kabata-Pendias and Pendias 1992). It has been reported that a limited number of wild plants are able to grow normally on metal-contaminated sites and accumulate high concentrations of $\mathrm{Cu}$ in their tissues without suffering any damage (Baker and Brooks 1989). Depending on the species, plants have evolved several mechanisms for metal detoxification, including exclusion, compartmentalization, chelation, and binding to organic ligands such as organic acids, amino acids, phytochelations (PCs), and metallothioneins (MTs) (Cobbett and Goldbrough 2002; Hall 2002).

MTs are low-molecular weight cysteine (Cys)-rich proteins that can effectively bind metals via their Cys residues (Cobbett and Goldbrough 2002). As shown by the molecular structure of the $\mathrm{Cu}-\mathrm{MT}$ complex, MTs have a high Cu-binding capacity (Callahan et al. 2006). Based on the arrangement of Cys residues, MTs have been divided into three classes. All plant MTs belong to Class II and typically contain two structural metal-binding Cys-rich domains at their $\mathrm{N}$ - and $\mathrm{C}$-terminal regions. Many genes encoding MTs have been isolated and characterized in plants, but the precise functions of MTs are not completely understood, partly because it is difficult to isolate the proteins intact from plant tissues. Evidence suggests that plant MTs play a role in maintaining the homeostasis of essential metal ions, detoxifying heavy metals, and scavenging reactive oxygen species (ROS) (Cobbett and 
Goldbrough 2002; Mir et al. 2004; Wong et al. 2004; Nishiuchi et al. 2007; Xue et al. 2009). In some plant species, $\mathrm{Cu}$ tolerance is associated with constitutively enhanced transcript levels of a type 2 MT (Murphy and Taiz 1995; van Hoof et al. 2001; Mengoni et al. 2003). Gene expression analyses and functional testing in yeast have revealed a role for MTs in $\mathrm{Cu}$ homeostasis and detoxification (Zhou and Goldsbrough 1994; Ma et al. 2003; Roosens et al. 2004; Hassinen et al. 2007). In addition, plant MTs are involved in important physiological processes, including fruit ripening (Moyle et al. 2005), root development, embryo germination (Yuan et al. 2008), and suberization (Mir et al. 2004).

Elsholtzia haichowensis Sun, in the Lamiaceae, is a $\mathrm{Cu}$ accumulator widely distributed on $\mathrm{Cu}$-mining waste and $\mathrm{Cu}$ contaminated soil along the middle and lower reaches of the Yangtze River in China (Tang et al. 1999; Lou et al. 2004; Qian et al. 2005). It has been suggested that the $\mathrm{Cu}$ tolerance of E. haichowensis is based on an exclusion mechanism, similar to that of Silene vulgaris (Song et al. 2004). The concentration of $\mathrm{Cu}$ in the roots of E. haichowensis is much higher than that in shoots, and most of this $\mathrm{Cu}$ is bound to root cell walls (more than $60 \%$ of the total) (Lou et al. 2004). However, our and other studies have shown that E. haichowensis can accumulate $\mathrm{Cu}$ at levels exceeding $100 \mu \mathrm{g} / \mathrm{g}$ DW in the shoots (Lou et al. 2004; Song et al. 2004; Qian et al. 2005), which is much higher than the toxicity threshold of 20-30 $\mu \mathrm{g} / \mathrm{g}$ DW reported in $\mathrm{Cu}$ non-tolerant crop species (Marschner 1995). Using synchrotron radiation X-ray fluorescence spectroscopy (SRXRF), Shi et al. (2008) demonstrated that the relative $\mathrm{Cu}$ levels were much higher in mesophyll tissue than in the leaf epidermis. These results imply that E. haichowensis employs an internal mechanism to tolerate the elevated levels of $\mathrm{Cu}$ in shoot tissues, in addition to its exclusion mechanism. Qian et al. (2005) reported that protein thiols might be involved in the adaptive tolerance mechanisms in response to $\mathrm{Cu}$ toxicity in this plant. However, the molecular mechanisms underlying the $\mathrm{Cu}$ tolerance of E. haichowensis are unclear. In this study, we isolated an MTl-type gene from E. haichowensis, and investigated its expression pattern in various organs. Moreover, the $\mathrm{Cu}$ tolerance and accumulation in Escherichia coli expressing EhMT1 were analyzed. Transient EhMT1-GUS expression was also analyzed in onion epidermal cells. The aim of this study was to increase our understanding of the $\mathrm{Cu}$-tolerance mechanisms in $\mathrm{Cu}$-accumulating plants.

\section{Materials and methods}

Plant materials and bacterial stains

Seeds of $E$. haichowensis were collected from $\mathrm{Cu}$ mine tailings near Tongling, Anhui Province, China. Seedlings were grown hydroponically in a greenhouse with a 12-h photoperiod at $25{ }^{\circ} \mathrm{C}$ and at $20{ }^{\circ} \mathrm{C}$ in darkness for 1 month before treatment. The plants were then exposed to $50 \mu \mathrm{M}$ $\mathrm{CuSO}_{4}$ for $48 \mathrm{~h}$, heat shocked at $42{ }^{\circ} \mathrm{C}$, and treated with $0.01 \% \mathrm{H}_{2} \mathrm{O}_{2}$ for $1 \mathrm{~h}$. All treatments were repeated three times; the results represent the means of three independent experiments. Subsequently, the shoots and roots were collected separately, frozen in liquid nitrogen, and stored at $-80{ }^{\circ} \mathrm{C}$ until use.

Escherichia coli strain JM109 was used for the cloning of all recombinant plasmid vectors, while $E$. coli strain BL21 (DE3) was used for His fusion expression. Agrobacterium tumefaciens strain EHA105 was used for the transformation of onion epidermal cells.

RNA isolation and first-strand cDNA synthesis

Total RNA was isolated from the collected samples using a Plant RNApure Kit (Tiangen, Beijing, China) according to the manufacturer's instructions. The quality and quantity of the RNA were assessed by measuring the A260/A280 ratio and by $1 \%$ agarose gel electrophoresis with ethidium bromide staining.

Single-stranded cDNA was synthesized using $1 \mu \mathrm{g}$ of total RNA and Oligd(T) $)_{18}$ primer with the Promega RTPCR system (Madison, WI, USA) in a total volume of $20 \mu \mathrm{L}$. The RT reaction was performed at $70^{\circ} \mathrm{C}$ for $10 \mathrm{~min}, 37^{\circ} \mathrm{C}$ for $1 \mathrm{~h}$, and $94{ }^{\circ} \mathrm{C}$ for $5 \mathrm{~min}$. One microliter of $100 \mathrm{U} / \mu \mathrm{l} \mathrm{M}-\mathrm{MLV}$ reverse transcriptase was added for $1 \mathrm{~h}$ at $37^{\circ} \mathrm{C}$.

\section{Cloning of the full-length cDNA}

To amplify the coding region of EhMT1, the cDNA was cloned using a pair of degenerate primers, P1 and P2, synthesized by Sangon (Shanghai, China). The PCR products were purified from agarose gels using a Gel Extraction Kit (Huashun, Shanghai, China), cloned into pGEM-T (Promega), and sequenced.

SMART RACE cDNA Amplification Kits (Clontech, Mountain View, CA, USA) were used to amplify the $5^{\prime}$ and $3^{\prime}$ ends of the cDNA to obtain the full-length cDNA sequence. Gene-specific nested primers were designed on the basis of the obtained sequence information. The genespecific and nested primers used for $5^{\prime}$ RACE were NGSP1 and NGSP2; the gene-specific primer for $3^{\prime}$ RACE was GSP. The PCR program was 29 cycles of $94{ }^{\circ} \mathrm{C}$ for $5 \mathrm{~s}$, $68{ }^{\circ} \mathrm{C}$ for $10 \mathrm{~s}$, and $72{ }^{\circ} \mathrm{C}$ for $2 \mathrm{~min}$.

\section{Semi-quantitative RT-PCR}

The primers used for semi-quantitative RT-PCR were P1 and P2 (for primer sequences, see Table 1). $18 S$ rRNA was 
Table 1 Primers used to clone the full-length EhMT1 cDNA, examine its expression, and assess expression of the fusion protein in E. coli

\begin{tabular}{ll}
\hline Primer name & Sequence \\
\hline P1 & $5^{\prime}$-GAAAATGTCTTGCTGTGG(T/A)GG-3' \\
P2 & $5^{\prime}$-GTGCAAGGGTTGCAGGTGCAG-3' \\
NGSP1 & $5^{\prime}$-ACCCCTTCAACGGAGATAAC-3' \\
NGSP2 & $5^{\prime}$-GCGATCTTCTCCACATCTGC-3' \\
GSP & $5^{\prime}$-TGCACGGTGAAGGATCTGAG-3' \\
18S & $5^{\prime}$-TGGGATACCTGCCAGTAGTCAT-3' \\
18A & $5^{\prime}$-CTGGATCCAATTACCAGACTCAA-3' \\
EcoP & $5^{\prime}$-GGATATCAAGAAAATGTCGAGTGGA-3' \\
BamP & $5^{\prime}$-GGATCCTCAGCAGGGCCTAGTTAA-3' \\
\hline
\end{tabular}

used as an internal control; the primers were $18 \mathrm{~S}$ and 18A. The EhMTI and 18S rRNA products were 225 and $500 \mathrm{bp}$ in length, respectively. All PCRs were replicated at least three times.

Expression of the EhMT1 fusion protein and analysis of $\mathrm{Cu}$ concentration in $E$. coli

EhMT1 was overexpressed in E. coli as a His fusion protein using the plasmid vector pET-30a. The coding region of EhMT1 was amplified by PCR using Taq Plus DNA polymerase with two primers (forward: EcoP, reverse: BamP) containing EcoRI and BamHI restriction sites, respectively. After digestion with EcoRI/BamHI, the EhMT1 coding region fragment was inserted into pET-30a using the same restriction sites. Sequence analysis of the coding regions of EhMTl did not reveal any mutations, and the recombinant vector was named pET-30a-EhMT1. Empty pET-30a and pET-30a-EhMT1 were transformed into E. coli BL21 (DE3) cells.

Escherichia coli cells transformed with pET-30aEhMT1 or pET-30a (control) were cultured in Luria-Bertani (LB) medium supplemented with $50 \mu \mathrm{g} / \mathrm{ml}$ kanamycin and shaking at $200 \mathrm{rpm}$ at $37{ }^{\circ} \mathrm{C}$. At an $\mathrm{OD}_{600}$ of $0.5-1.0$, the cells were induced with $1.0 \mathrm{mM}$ isopropyl- $\beta$-D-thiogalactopyranoside (IPTG), grown for an additional $3 \mathrm{~h}$, and harvested by centrifugation at $4,000 \mathrm{~g}$ for $10 \mathrm{~min}$. After boiling for $5 \mathrm{~min}, 15 \mu \mathrm{l}$ of the samples was analyzed by Coomassie blue staining using $15 \%$ SDS-polyacrylamide gels.

To test the effect of EhMT1 expression in E. coli, the growth of $E$. coli cells carrying empty pET-30a was compared with cells carrying pET-30a-EhMT1. Each strain was inoculated separately $\left(\mathrm{OD}_{600}=0.4\right)$ into $50 \mathrm{~mL}$ of $\mathrm{LB}$ medium with $1.0 \mathrm{mM}$ IPTG, with or without $1.0 \mathrm{mM}$ $\mathrm{CuSO}_{4}$. The cultures were shaken at $200 \mathrm{rpm}$ at $37{ }^{\circ} \mathrm{C}$, and the $\mathrm{OD}_{600}$ was measured at 2-h intervals.

The aliquots cultured in LB medium with $1.0 \mathrm{mM}$ $\mathrm{CuSO}_{4}$ for $4 \mathrm{~h}$ were centrifuged at $5,000 \mathrm{~g}$ for $10 \mathrm{~min}$. Cells were washed three times in LB medium, then dry weights were measured. The dried samples were completely digested with extra pure grade $\mathrm{HNO}_{3}$ and $\mathrm{HClO}_{4}$ (87:13, $\mathrm{v} / \mathrm{v})$. The concentration of $\mathrm{Cu}$ was determined by flame atomic absorption spectrometer $\left(\right.$ novAA ${ }^{\circledR} 400$; Analytik Jena, Jena, Germany). Blanks were also used for background correction and other sources of error.

Analysis of transient EhMT1-GUS expression

To generate the construct EhMT1-GUS ( $\beta$-glucuronidase) for the transformation of onion epidermal cells, a XbaIBam HI fragment containing the coding region of the EhMT1 fusion GUS cassette was inserted into the XbaIBamHI site in pBI121 (Clontech).

GUS staining was conducted according to Jefferson et al. (1987). Onion epidermal samples were vacuum infiltrated and then incubated in X-gluc solution $[1 \mathrm{mM}$ $\mathrm{X}$-gluc, $50 \mathrm{mM}$ sodium phosphate buffer $(\mathrm{pH} 7.2)$, and $5 \mathrm{mM}$ potassium ferricyanide] for $8 \mathrm{~h}$ at $37{ }^{\circ} \mathrm{C}$. Next, the samples were washed with $70 \%(\mathrm{~V} / \mathrm{V})$ ethanol at $60{ }^{\circ} \mathrm{C}$ for $2 \mathrm{~h}$ and photographed under a stereomicroscope (SZX21; Olympus). More than six individual samples were stained and analyzed.

\section{Results}

\section{EhMT1 encodes a type $1 \mathrm{MT}$}

RT-PCR and RACE were used to obtain full-length cDNA fragments of interest. The sequences of the clones were identified using a BLAST search (http:॥www.ncbi.nlm.nih. gov/BLAST). The cDNA, which showed strong similarity to the cDNA of MT1 (CAA36249), was named EhMT1 and submitted to GenBank under accession number DQ059081. The cDNA contained a 225-bp open reading frame (data not shown) encoding a 74 amino acid polypeptide with a theoretical molecular mass of $7.14 \mathrm{kDa}$ and a $p \mathrm{I}$ of 5.13 . Similar to other plant MTs, there was no Cys in the spacer region between the terminal Cys-rich domains (Fig. 1). A sequence alignment of the EhMTI cDNA with genomic DNA revealed that EhMTl contains two introns starting with the typical $5^{\prime}$-GT and ending with AG-3' in the genomic DNA (data not shown). The intron sizes were 197 and $90 \mathrm{bp}$, respectively.

A multiple sequence alignment was conducted with EhMT1 and other proteins, including MgMT1 (CAA36249) from Mimulus guttatus, PmMT1 (CAH59439) from Plantago major, and IbMT1 (BAD95644) from Ipomoea batatas (Fig. 1a). Type 1 MTs contain two Cys-rich domains separated by a spacer of approximately 40 amino acids. The $\mathrm{N}$-terminal sequence in this type of MT is highly conserved, 
Fig. 1 Comparison of the deduced amino acid sequence for EhMT1 with that for other MTs (a), phylogenetic tree analysis (b)

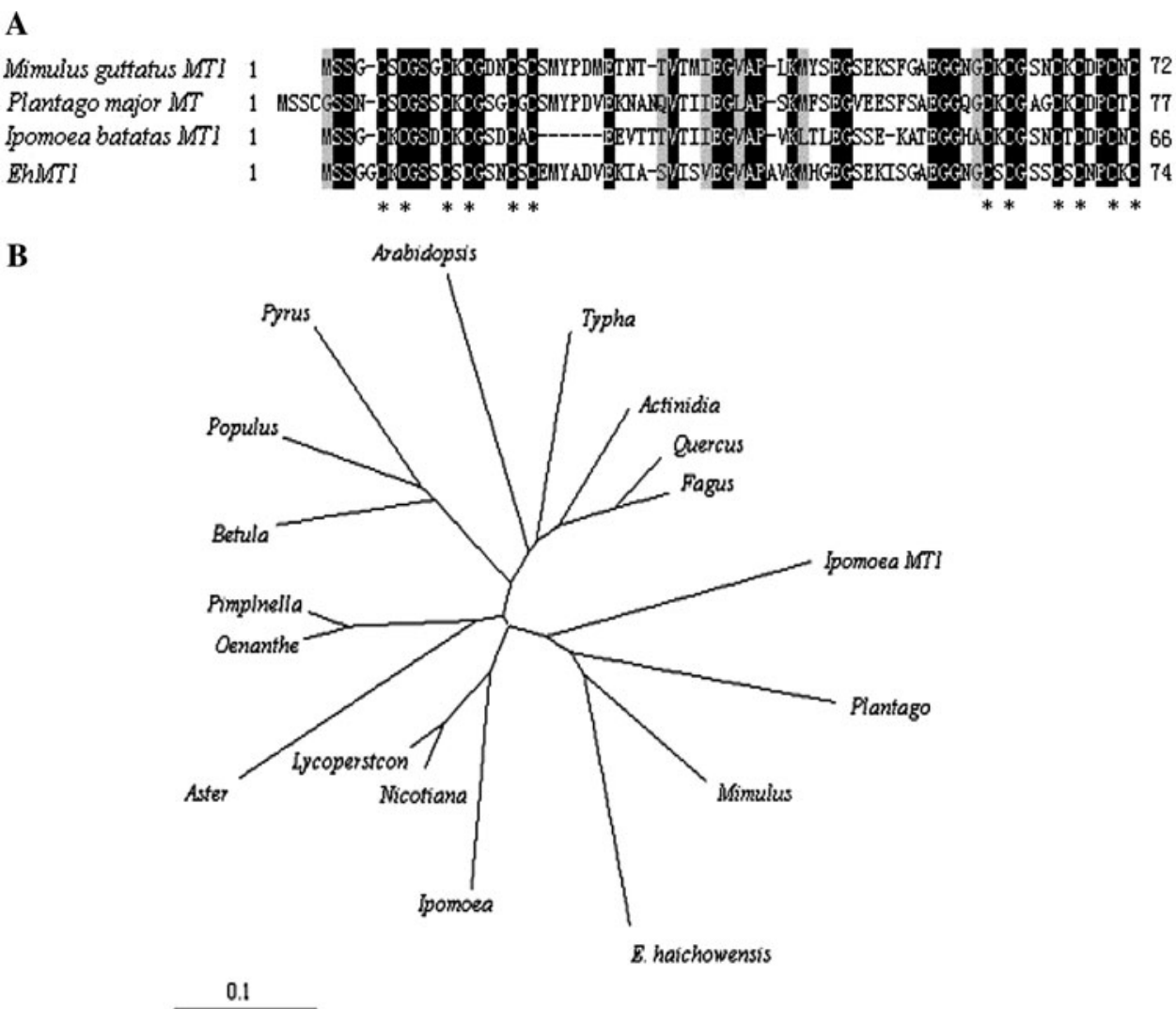

and the C-terminal domain contains three Cys-Xaa-Cys motifs (Fig. 1a). Plant MTs have been divided into different types based on the arrangement of the Cys residues at their $\mathrm{N}$ - and C-termini (Robinson et al. 1993; Rauser 1999). The 18 proteins were divided into several small subgroups by phylogenetic analysis (Fig. 1b); EhMT1 was clustered with MgMT1, PmMT1, and IbMT1. Therefore, we classified EhMT1 as a type 1 MT. Our analysis indicates that homologous MT1 genes exist ubiquitously in planta, suggesting that this gene family plays important roles in higher plants; thus, we chose EhMT1 for further study.

\section{Analysis of EhMTl expression}

EhMT1 expression was investigated using semi-quantitative RT-PCR. The EhMT1 transcript level was higher in roots than in leaves, and it was weak in stems (Fig. 2a). To investigate whether metal ions, heat, or oxidative stress are involved in the regulation of EhMTl, we harvested $E$. haichowensis seedlings treated with $\mathrm{Cu}$, heat, or oxidative stress and assessed the transcriptional level of EhMT1. EhMT1 expression was markedly increased in both roots and leaves treated with $\mathrm{Cu}$ and $\mathrm{H}_{2} \mathrm{O}_{2}$; in contrast, heat shock did not increase root EhMT1 expression (Fig. 2b).

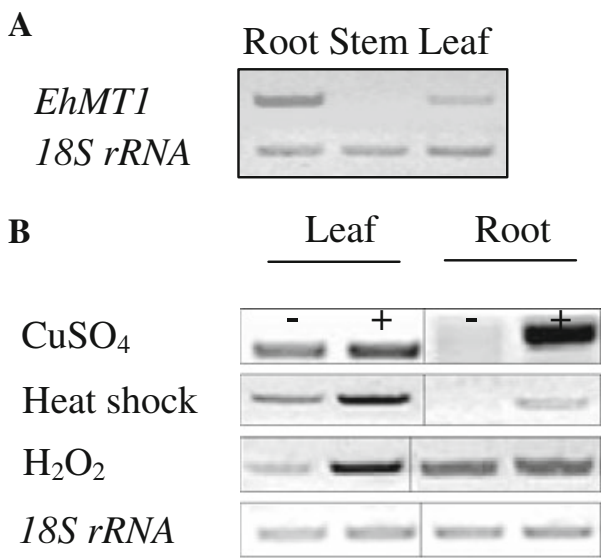

Fig. 2 Expression analysis of EhMT1 as determined by semiquantitative RT-PCR. EhMT1 mRNA levels in the roots, stems, and leaves of E. haichowensis (a); EhMT1 mRNA levels in leaves and roots of plants exposed to $50 \mu \mathrm{M} \mathrm{CuSO}$ for $48 \mathrm{~h}$, heat shocked at $42{ }^{\circ} \mathrm{C}$ for $1 \mathrm{~h}$, and treated with $0.01 \% \mathrm{H}_{2} \mathrm{O}_{2}$ for $1 \mathrm{~h}$ (b). $18 S \mathrm{rRNA}$ was used as an internal control

Efficient expression of functional EhMT1 as a fusion protein in E. coli

Figure 3 shows the expression of the $18-\mathrm{kDa}$ fusion protein in BL21 (DE3) cells transformed with pET-30a-EhMT1 


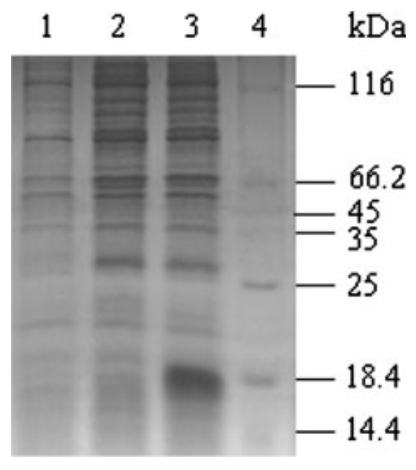

Fig. 3 Expression of EhMT1 in E. coli. Bacterial lysates from E. coli cells transformed with: (1) empty vector (pET-30a) without IPTG induction, (2) pET-30a with IPTG induction, and (3) recombinant plasmid (pET-30a-EhMT1) with IPTG induction, (4) protein markers, including $\beta$-galactosidase $(116 \mathrm{kDa})$, BSA $(66.2 \mathrm{kDa})$, ovalbumin $(45 \mathrm{kDa})$, lactate dehydrogenase $(35 \mathrm{kDa})$, endonuclease Bsp $98 \mathrm{I}$ (25 kDa), $\beta$-lactoglobulin $(18.4 \mathrm{kDa})$, and lysozyme $(14.4 \mathrm{kDa})$

and induced with IPTG. To confirm the function of EhMTI in vivo, bacterial growth in the presence of $\mathrm{Cu}$ was compared using empty vector (pET-30a)- and pET-30aEhMT1-expressing cells. The pET-30a-EhMT1 transformed cells showed significantly improved growth in LB media supplemented with $1.0 \mathrm{mM} \mathrm{CuSO}$, whereas the growth of control cells carrying the empty vector was significantly inhibited. In the absence of $\mathrm{Cu}$, the two strains exhibited identical growth kinetics (Fig. 4). The concentration of $\mathrm{Cu}$ in E. coli cells expressing EhMT1 was approximately 1.6 -fold greater than that in expressing empty vector cells when exposed to $1 \mathrm{mM} \mathrm{CuSO}_{4}$ for $4 \mathrm{~h}$ (Fig. 5).

Transient expression of EhMT1 in onion epidermal cells

To identify the cellular compartment in which EhMT1 functions, we assessed the location of EhMT1 in onion epidermal cells. When EhMT1 fused with GUS under the control of the cauliflower mosaic virus $35 \mathrm{~S}$ promoter was introduced into onion epidermal cells (Fig. 6a), GUS staining was localized into the cytoplasm. Cytoplasmic localization was also observed in onion epidermal cells expressing 35S-GUS (Fig. 6b).

\section{Discussion}

According to the classification system proposed by Cobbett and Goldbrough (2002), plant MTs are subdivided into four types based on their primary sequences, and specifically on the positions of their Cys residues. Type 1 MTs possess CXCXXXCXCXXXCXXC and CXCXXXCXCXXCXC (X corresponds to amino acids other than Cys) motifs at their N- and C-termini, respectively (Cobbett and Goldbrough 2002). As shown in this study, the $M T$ cDNA isolated from E. haichowensis encodes a protein with two Cys-rich regions. These regions show significant identity with the $\mathrm{N}$ - and $\mathrm{C}$-terminal domains of different type 1 MTs from other plants; therefore, the MT was designated EhMT1. EhMT1 exhibits a high degree of similarity to the type 1 MT from M. guttatus (de Miranda et al. 1990), a Cu-tolerant plant, indicating that EhMT1 may perform functions similar to the M. guttatus MT. To verify the identity of the isolated cDNA, genomic fragments covering the coding region were isolated by PCR and sequenced. Our results indicate that the genomic fragments were divided into three exons by two introns (data not shown). $M T$ genes with two introns have been reported in rice and cotton (Hudspeth et al. 1996; Chen et al. 1998).

It has been reported that different members of the plant $M T$ gene family show distinct spatial and temporal expression patterns, probably correlated with distinct roles in plant tissues (Guo et al. 2003, 2008). In general, type 1 $M T s$ are predominantly expressed in roots, whereas type 2 and $3 M T$ genes are mainly expressed in shoots (Zhou and Goldsbrough 1994, 1995; Hsieh et al. 1995, 1996; Guo
Fig. 4 Growth curves of E. coli BL21 (DE) carrying pET-30aEhMT1 or empty vector in the absence (a) or presence (b) of $1.0 \mathrm{mM} \mathrm{CuSO}_{4}$. The results are the mean $\pm \mathrm{SE}$ of three independent experiments
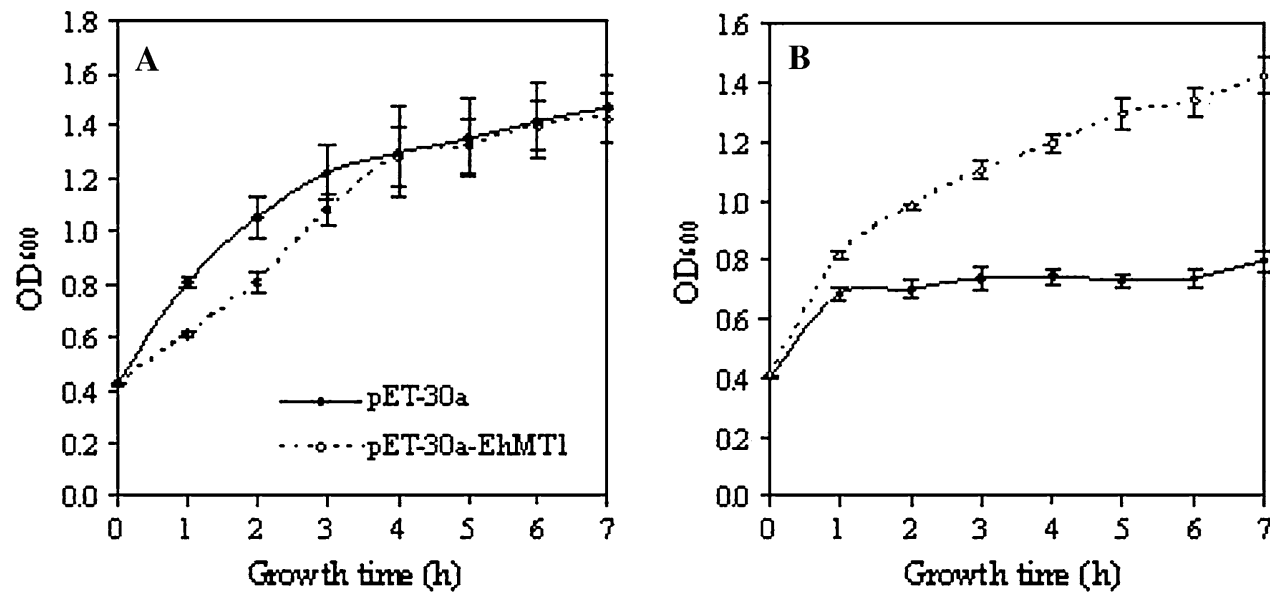


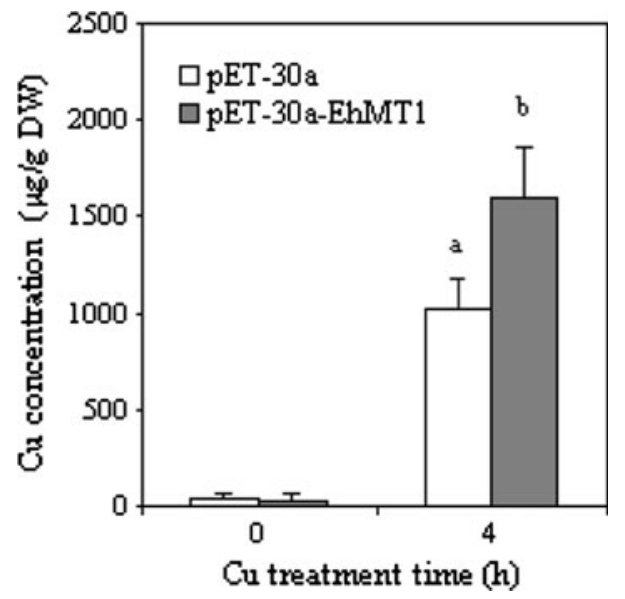

Fig. 5 The $\mathrm{Cu}$ concentration in E.coli cultured in LB medium with $1.0 \mathrm{mM} \mathrm{CuSO}{ }_{4}$ for $4 \mathrm{~h}$. The results are the mean $\pm \mathrm{SE}$ of three independent experiments

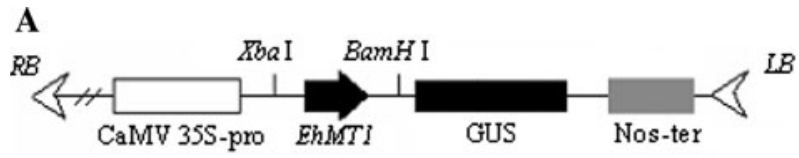

B

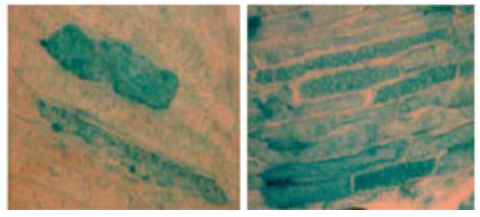

Fig. 6 Subcellular localization of EhMT1 overexpressed in onion epidermal cells. a Schematic diagram of the pBI121 expression vector. b Colocalization of 35S-GUS (left, control) and 35S-EhMT1GUS (right) in the cytoplasm of onion epidermal cells

et al. 2003; Castiglione et al. 2007). Guo et al. (2003) further found that MTla and MT2b were expressed in the phloem of Arabidopsis leaves and roots, whereas MT2a and MT3 were mainly expressed in root tips and young leaves. In the present study, EhMTl RNA was detected in the leaves of E. haichowensis although the level was lower than that in the roots. It is possible that MT2, MT3, and MT4 homologs are also present in E. haichowensis. Further studies, analyzing other $M T$ family members are needed to confirm the effect of $\mathrm{Cu}$ on $M T$ expression in E. haichowensis.

Plant $M T$ gene expression has been shown to be regulated by many factors, including metal ions, stresses such as salt, heat shock, wounding, and $\mathrm{H}_{2} \mathrm{O}_{2}$, and developmental stage. Our data indicate that EhMTl is induced by treatments with $\mathrm{Cu}, \mathrm{H}_{2} \mathrm{O}_{2}$, and heat shock. The expression of plant type $1 M T$ genes is induced by $\mathrm{Cu}$ in a number of plant species (Zhou and Goldsbrough 1994; Hsieh et al. 1995; Snowden et al. 1995; Choi et al. 1996; García-Hernández et al. 1998; Morris et al. 1999; Giordani et al. 2002; Ma et al. 2003; Guo et al. 2003; Roosens et al. 2004). In this study, $\mathrm{Cu}$ treatment increased EhMTl expression more strongly in roots than in leaves. This suggests a particular role for EhMT1 in Cu tolerance in E. haichowensis roots. Guo et al. (2008) observed that MT1a but not MT2b deficiency led to a $30 \%$ decrease in $\mathrm{Cu}$ accumulation in Arabidopsis roots, suggesting that MT1a functions in the sequestration of excess $\mathrm{Cu}$ in root cells. It has been shown that the $\mathrm{Cu}$ tolerance of $E$. haichowensis involves the accumulation of $\mathrm{Cu}$ in roots and the restricted translocation of $\mathrm{Cu}$ toward shoots, thereby excluding this metal from regions of active growth and metabolism (Lou et al. 2004; Song et al. 2004). Ni et al. (2005) confirmed that the isolation of $\mathrm{Cu}$ in vacuoles may be involved in the detoxification process in roots of $E$. haichowensis.

Our data support the hypothesis that MTl genes are involved in $\mathrm{Cu}$ tolerance and accumulation in plants. $E$. coli cells expressing pET-30a-EhMT1 were more tolerant to $\mathrm{Cu}$ exposure and accumulated more $\mathrm{Cu}$ than control cells. Similar results were reported in E. coli expressing $P S M T_{A}$ and $r g M T$ (Evans et al. 1992; Jin et al. 2006). AtMTl from Arabidopsis enhances $\mathrm{Cu}$ resistance in yeast cells (Zhou and Goldsbrough 1994). Functional complementation studies have shown that $m c M T 1$ from the metal-tolerant grass Festuca rubra functions to sequester $\mathrm{Cu}$ and other metal ions (Ma et al. 2003).

To elucidate the function of a protein, it is important to know its location. It has been difficult for MT proteins in planta, since cell fractionation destroys MT proteins that are unstable in the presence of oxygen (Lee et al. 2004). We showed that EhMT1 fused to GUS was localized in the cytosol of onion epidermal cells, indicating that EhMT1 may bind $\mathrm{Cu}$ in the cytoplasm, thereby decreasing the activity of free $\mathrm{Cu}^{2+}$ ion and blocking $\mathrm{Cu}^{2+}$ from interacting with cytoplasmic components in E. haichowensis. It has already been shown that the AtMT2a and AtMT3, and BjMT2 were localized in the cytoplasm of the Vicia faba guard cells and tobacco leaf cells, respectively, and that this localization did not change after $\mathrm{Cd}$ or $\mathrm{Cu}$ treatment (Lee et al. 2004; An et al. 2006). On the other hand, MT protein itself might act as an endogenous antioxidant since the cys ligands in proteins are remarkably reactive toward oxidizing agents (Chae et al. 1994).

Oxidative burst is a common response to abiotic and biotic stresses. To avoid the deleterious effect of ROS, plant cells have evolved antioxidant defense mechanisms, which include enzymatic and non-enzymatic components (Mittler 2002). MTs themselves are considered to be antioxidants in plant systems (Cobbett and Goldbrough 2002). In this study, enhanced EhMTl transcription in the roots and leaves of $E$. haichowensis was found in response to $\mathrm{H}_{2} \mathrm{O}_{2}$ exposure. This observation is consistent with studies of the oxidative stress-induced expression of MTs in other plant species, including Chloris virgata (Nishiuchi 
et al. 2007), Gossypium hirsutum (Xue et al. 2009), and Arabidopsis (Zhu et al. 2009). The treatment of Arabidopsis cotyledon and leaf tissues with a catalase inhibitor resulted in enhanced expression of LSC54, a rape MT1 gene (Navabpour et al. 2003). Combined treatment with quenchers of ROS indicated that this induced expression was due to increased levels of ROS. Transgenic Arabidopsis plants overexpressing BrMT1 from Brassica rapa (Kim et al. 2007) or cgMT1 from Casuarina glauca (Obertello et al. 2007) show reduced accumulation of $\mathrm{H}_{2} \mathrm{O}_{2}$. Under conditions of high salinity, drought, and low temperature, the $\mathrm{H}_{2} \mathrm{O}_{2}$ levels in tobacco seedlings overexpressing GhMt3a from G. hirsutum were only half that in control plants (Xue et al. 2009). Transgenic yeast overexpressing GhMT3a showed high levels of tolerance to ROS stress. Purified OsMT2b demonstrated greater protection against hydroxyl radical-mediated salicylate hydroxylation compared to the vector (GST) alone (Wong et al. 2004). We previously demonstrated that excess $\mathrm{Cu}$ treatment induced oxidative stress and increased the accumulation of superoxide anion $\left(\mathrm{O}_{2}^{--}\right)$and $\mathrm{H}_{2} \mathrm{O}_{2}$ in E. haichowensis roots and leaves (Zhang et al. 2008, 2010). The increased need for MT caused by $\mathrm{Cu}$ and $\mathrm{H}_{2} \mathrm{O}_{2}$ treatment suggests a role for EhMT1 in ROS scavenging. In this study, however, the role of oxidative signaling in the expression of $M T$ genes was not clarified. Other oxidative stressors and signaling molecules will be investigated to define the regulation of $M T$ genes in this plant species.

Heat shock had obvious effects on the expression of EhMT1 in roots and leaves. Thus, EhMT1 may be involved in heat shock responses. Similarly, it has been shown that heat shock induces the expression of $O s M T-1$ and -2 in rice (Hsieh et al. 1995, 1996).

\section{Conclusions}

The present study showed that EhMT1 expression in E. haichowensis was induced by $\mathrm{Cu}, \mathrm{H}_{2} \mathrm{O}_{2}$, and heat shock. The tolerance of $E$. coli expressing pET-30a-EhMT1 to $\mathrm{Cu}$ stress was improved compared with control cells. Our results suggest that EhMT1 functions to moderate the toxicity of $\mathrm{Cu}$ ions; however, the detailed mechanism remains to be elucidated.

Author contribution Zhenguo Shen designed and instructed the research work. Yan Xia, Yanyan Lv and Yuxiang Yuan performed the experiments. Guiping Wang and Yahua Chen contributed the data analysis. Yan Xia, Zhenguo Shen, and Hongsheng Zhang wrote the manuscript.

Acknowledgments This study was supported by Doctoral Program Foundation of Institutions of Higher Education of China (20070307010).
Open Access This article is distributed under the terms of the Creative Commons Attribution License which permits any use, distribution, and reproduction in any medium, provided the original author(s) and the source are credited.

\section{References}

An ZG, Li CJ, Zu YG, Du YJ, Wachter A, Gromes R, Rausch T (2006) Expression of BjMT2, a metallothionein 2 from Brassica juncea, increases copper and cadmium tolerance in Escherichia coli and Arabidopsis thaliana, but inhibits root elongation in Arabidopsis thaliana seedlings. J Exp Bot 57(14):3575-3582

Baker AJM, Brooks RR (1989) Terrestrial higher plants which hyperaccumulate metallic elements-a review of their distribution, ecology and phytochemistry. Biorecovery 1:81-126

Callahan DL, Baker AJ, Kolev SD, Wedd AG (2006) Metal ion ligands in hyperaccumulating plants. J Biol Inorg Chem 11:2-12

Castiglione S, Franchin C, Fossati T, Lingua G, Torrigiani P, Biondi S (2007) High zinc concentrations reduce rooting capacity and alter metallothionein gene expression in white poplar (Populus alba L. cv. Villafranca). Chemosphere 67:1117-1126

Chae HZ, Uhm TB, Rhee SG (1994) Dimerization of thiol-specific antioxidant and the essential role of cysteine-47. P Natl Acad Sci USA 91:7022-7026

Chen WM, Hsieh HM, Huang PC (1998) Type 2 rice metallothioneinlike gene has two introns. DNA Seq 8:223-228

Choi D, Kim HM, Yun HK, Park JA, Kim WK, Bok SH (1996) Molecular cloning of a metallothionein-like gene from Nicotiana glutinosa $\mathrm{L}$. and its induction by wounding and tobacco mosaic virus infection. Plant Physiol 112:353-359

Cobbett C, Goldbrough PB (2002) Phytochelatins and metallathioneins: roles in heavy metal detoxification and homeostasis. Annu Rev Plant Biol 53:159-182

de Miranda JR, Thomas MA, Thurman DA, Tomsett AB (1990) Metallothionein genes from the flowering plant Mimulus guttatus. FEBS Lett 260:277-280

Evans KM, Gatehouse JA, Lindsay WP, Shi JG, Tommey AM, Robinson NJ (1992) Expression of the pea metallothionein-like gene $P S M T_{A}$ in Escherichia coli and Arabidopsis thaliana and analysis of trace metal ion accumulation: implications for $P s M T_{A}$ function. Plant Mol Biol 20:1019-1028

García-Hernández M, Murphy A, Taiz L (1998) Metallothioneins 1 and 2 have distinct but overlapping expression patterns in Arabidopsis. Plant Physiol 118:387-397

Giordani T, Natali L, Maserti BE, Taddei S, Cavallini A (2002) Characterization and expression of DNA sequences encoding putative type-II metallothioneins in the seagrass Posidonia oceanica. Plant Physiol 123:1571-1581

Guo WJ, Bundithya W, Goldsbrough PB (2003) Characterization of the Arabidopsis metallothionein gene family: tissue-specific expression and induction during senescence and in response to copper. New Phytol 159:369-381

Guo WJ, Meetam M, Goldsbrough PB (2008) Examining the specific contributions of individual Arabidopsis metallothioneins to copper distribution and metal tolerance. Plant Physiol 146: $1697-1706$

Hall JL (2002) Cellular mechanisms for heavy metal detoxification and tolerance. J Exp Bot 53:1-11

Hassinen VH, Tervahauta AI, Halimaa P, Plessl M, Peräniemi S, Schat H, Aarts MGM, Servomaa K, Kärenlampi SO (2007) Isolation of $\mathrm{Zn}$-responsive genes from two accessions of the hyperaccumulator plant Thlaspi caerulescens. Planta 225:977989 
Hsieh HM, Liu WK, Huang PC (1995) A novel stress-inducible metallothionein-like gene from rice. Plant Mol Biol 28:381-389

Hsieh HM, Liu WK, Chang A, Huang PC (1996) RNA expression patterns of a type 2 metallothionein-like gene from rice. Plant Mol Biol 32:525-529

Hudspeth RL, Hobbs SL, Anderson DM, Rajasekaran K, Grula JW (1996) Characterization and expression of metallothionein-like genes in cotton. Plant Mol Biol 31:701-705

Jefferson RA, Kavanagh TA, Bevan MW (1987) Gus fusions-betaglucuronidase as a sensitive and versatile gene fusion marker in higher-plants. EMBO J 6:3901-3907

Jin SM, Cheng YX, Guan QJ, Liu DL, Takano T, Liu SK (2006) A metallothionein-like protein of rice (rgMT) functions in $E$. coli and its gene expression is induced by abiotic stresses. Biotechnol Lett 28:1749-1753

Kabata-Pendias A, Pendias H (1992) Trace elements in soils and plants, 2nd edn. CRC Press, Boca Raton

Kim SH, Lee HS, Song WY, Choi KS, Hur H (2007) Chloroplasttargeted BrMT1 (Brassica rapa type-1 metallothionein) enhances resistance to cadmium and ROS in transgenic Arabidopsis plants. J Plant Biol 50(1):1-7

Lee J, Shim D, Song WY, Hwang I, Lee Y (2004) Arabidopsis metallothioneins $2 \mathrm{a}$ and 3 enhance resistance to cadmium when expressed in Vicia faba guard cells. Plant Mol Biol 54:805-815

Lou LQ, Shen ZG, Li XD (2004) The copper tolerance mechanisms of Elsholtzia haichowensis, a plant from copper-enriched soils. Environ Exp Bot 51:111-120

Ma M, Lau PS, Jia YT, Tsang WK, Lam SKS, Tam NFY, Wong YS (2003) The isolation and characterization of type 1 metallothionein (MT) cDNA from a heavy-metal-tolerant plant, Festuca rubra cv Merlin. Plant Sci 164:51-60

Marschner H (1995) Mineral nutrition of higher plants, 2nd edn. Academic Press, London

Mengoni A, Gonnelli C, Hakvoort HWJ, Galardi F, Bazzicalupo M, Gabbrielli R, Schat H (2003) Evolution of copper-tolerance and increased expression of a $2 \mathrm{~b}$-type metallothionein gene in Silene paradoxa L. populations. Plant Soil 257:451-457

Mir G, Domenech J, Huguet G, Guo WJ, Goldsbrough P, Atrian S, Molinas M (2004) A plant type 2 metallothionein (MT) from cork tissue responds to oxidative stress. J Exp Bot 55:2483-2493

Mittler R (2002) Oxidative stress, antioxidants and stress tolerance. Trends Plant Sci 7:405-410

Morris CA, Nicolaus B, Sampson V, Harwood JL, Kille P (1999) Identification and characterization of a recombinant metallothionein protein from a marine alga, Fucus vesiculosus. Biochem $\mathrm{J}$ 338:553-560

Moyle R, Fairbairn DJ, Ripi J, Crowe M, Botella JR (2005) Developing pineapple fruit has a small transcriptome dominated by metallothionein. J Exp Bot 56:101-112

Murphy A, Taiz L (1995) Comparison of metallothionein gene expression and nonprotein thiols in ten Arabidopsis ecotypescorrelation with copper tolerance. Plant Physiol 109:945-954

Navabpour S, Morris K, Allen R, Harrison E, A-H-Mackerness S, Buchanan-Wollaston V (2003) Expression of senescenceenhanced genes in response to oxidative stress. J Exp Bot 54:2285-2292

Ni CY, Chen YX, Lin Q, Tian GM (2005) Subcellular localization of copper in tolerant and non-tolerant plant. J Environ Sci China 17:452-456

Nishiuchi S, Liu SK, Takano T (2007) Isolation and characterization of a metallothionein-1 protein in Chloris virgata Swartz that enhances stress tolerances to oxidative, salinity and carbonate stress in Saccharomyces cerevisiae. Biotechnol Lett 29:13011305
Obertello M, Wall L, Laplaze L, Nicole M, Auguy F, Gherbi H, Bogusz D, Franche C (2007) Functional analysis of the metallothionein gene cgMT1 isolated from the actinorhizal tree Casuarina glauca. Mol Plant Microbe In 20:1231-1240

Qian M, Li XD, Shen ZG (2005) Adaptive copper tolerance in Elsholtzia haichowensis involves production of $\mathrm{Cu}$-induced thiol peptides. Plant Growth Regul 47:65-73

Rauser WE (1999) Structure and function of metal chelators produced by plants - the case for organic acids, amino acids, phytin, and metallothioneins. Cell Biochem Biophys 31:19-48

Robinson NJ, Tommey AM, Kuske C, Jackson PJ (1993) Plant metallothioneins. Biochem J 295:1-10

Roosens NH, Bernard C, Leplae R, Verbruggen N (2004) Evidence for copper homeostasis function of metallothionein (MT3) in the hyperaccumulator Thlaspi caerulescens. FEBS Lett 577:9-16

Shi JY, Wu B, Yuan XF, Cao YY, Chen XC, Chen YX, Hu TD (2008) An X-ray absorption spectroscopy investigation of speciation and biotransformation of copper in Elsholtzia splendens. Plant Soil 302:163-174

Snowden KC, Richards KD, Gardner RC (1995) Alumium-induced genes-induction by toxic metals, low-calcium, and wounding and pattern of expression in root-tips. Plant Physiol 107:341-348

Song J, Zhao FJ, Luo YM, McGrath SP, Zhang H (2004) Copper uptake by Elsholtzia splendens and Silene vulgaris and assessment of copper phytoavailability in contaminated soils. Environ Pollut 128:307-315

Tang SR, Wilke BM, Huang CY (1999) The uptake of copper by plants dominantly growing on copper mining spoils along the Yangtze River, the People's Republic of China. Plant Soil 209:225-232

van Hoof NALM, Hassinen VH, Hakvoort HWJ, Ballintijn KF, Schat H, Verkleij JAC, Ernst WHO, Karenlampi SO, Tervahauta AI (2001) Enhanced copper tolerance in Silene vulgaris (Moench) Garcke populations from copper mines is associated with increased transcript levels of a 2b-type metallothionein gene. Plant Physiol 126:1519-1526

Wong HL, Sakamoto T, Kawasaki T, Umemura K, Shimamoto K (2004) Down-regulation of metallothionein, a reactive oxygen scavenger, by the small GTPase OsRac1 in rice. Plant Physiol 135:1447-1456

Xue TT, Li XZ, Zhu W, Wu C, Yang GD, Zheng CC (2009) Cotton metallothionein GhMT3a, a reactive oxygen species scavenger, increased tolerance against abiotic stress in transgenic tobacco and yeast. J Exp Bot 60:339-349

Yuan J, Chen D, Ren YJ, Zhang XL, Zhao J (2008) Characteristic and expression analysis of a metallothionein gene, OsMT2b, downregulated by cytokinin suggests functions in root development and seed embryo germination of rice. Plant Physiol 146:1637-1650

Zhang HX, Xia Y, Wang GP, Shen ZG (2008) Excess copper induces accumulation of hydrogen peroxide and increases lipid peroxidation and total activity of copper-zinc superoxide dismutase in roots of Elsholtzia haichowensis. Planta 227:465-475

Zhang HX, Zhang FQ, Xia Y, Wang GP, Shen ZG (2010) Excess copper induces production of hydrogen peroxide in the leaf of Elsholtzia haichowensis through apoplastic and symplastic CuZn-superoxide dismutase. J Hazard Mater 178:834-843

Zhou JM, Goldsbrough PB (1994) Functional homologs of fungal metallothionein genes from Arabidopsis. Plant Cell 6:875-884

Zhou JM, Goldsbrough PB (1995) Structure, organization and expression of the metallothionein gene family in Arabidopsis. Mol Gen Genet 248:318-328

Zhu W, Zhao DX, Miao Q, Xue TT, Li XZ, Zheng CC (2009) Arabidopsis thaliana metallothionein, AtMT2a, mediates ROS balance during oxidative stress. J Plant Biol 52:585-592 